RUi DiaO

ORCID 0000-0003-1028-453X

Jiamusi University, Chiny

\title{
FACTORS FOR CHINESE STUDENTS CHOOSING POLAND HIGHER EDUCATION
}

\begin{abstract}
Diao Rui, Factors for Chinese Students Choosing Poland Higher Education [Czynniki skłaniające chińskich studentów do wyboru polskiego szkolnictwa wyższego]. Studia Edukacyjne nr 56, 2020, Poznań 2020, pp. 421-434. Adam Mickiewicz University Press. ISSN 1233-6688. DOI: 10.14746/se.2020.56.23

As the world's second largest economy, China has attracted extensive attention from the rest of the world in various aspects. Education, as a way to export talent, has always been valued by the world. Although China's education industry is growing, many Chinese students still choose to study abroad. China is one of the world's leading exporters of international students. Poland, located in Europe, has a clean educational environment, advanced European knowledge and unique cultural charm. In recent years, Sino-Polish relations have grown so close that studying in Poland will be a good choice for Chinese students. This article mainly introduces the admission of Chinese elite universities and the study and life of Chinese students in Poland.
\end{abstract}

Key words: education, new college entrance examination, Poland, reasons for studying abroad

\section{How to get into China's elite universities}

Since the 1990s, the scale and quantity of higher education in China have expanded rapidly, and the cause of higher education has developed so rapidly that China has popularized higher education in the early 21st century. But the Gaokao is still an important way to select the elites. The subjects of Gaokao changed many times in history, and traditionally, examinees can choose liberal arts and science generally, both having a few same compulsory exam subjects such as: mathematics, Chinese, foreign language. In most areas of the country, examinees choose to study liberal arts or science in their second year of high school, while science examinees take the comprehensive examinations of Chinese, mathematics, foreign languages and science (physics + chemistry 
+ biology). Liberal arts examinees take comprehensive examinations of the Chinese, mathematics, foreign languages, literature and history (politics + geography + history). The Chinese and foreign language papers of science and engineering are the same as those of liberal arts. Some provinces have adopted different examination modes. The Gaokao implements the " $3+X$ " examination mode, where the examination is divided into science subjects and liberal arts subjects.

Table 1

\begin{tabular}{|l|c|c|}
\hline \multicolumn{1}{|c|}{ Subject of examination } & Full score & Total score of Gaokao \\
\hline Chinese & 150 & \\
\hline Mathematics & 150 & 750 \\
\cline { 1 - 2 } $\begin{array}{l}\text { Physics + Chemistry + Biology/ } \\
\text { History + Politics + Geography }\end{array}$ & 300 & \\
\hline Foreign language & 150 & \\
\hline
\end{tabular}

In recent years, China has carried out the reformation of Gaokao - new Gaokao. New Gaokao reform was officially started in September 2014 by the 'Opinions on Deepening Reform on Examination \& Recruitment System issued by the State Council ( "Opinions")'. The 'opinions' specifies the reform of exam subject setup, the need to enhance the correlation between Gaokao and high school learning and that the total score of the examinee is determined by the unified Gaokao examinations of Chinese, mathematics and foreign language with the same subjects and score scale, ,regardless of liberal arts and sciences, with two examination opportunities provided for foreign languages. The traditional division of liberal arts and sciences will be abolished. The New Gaokao has not fully implemented so far. Launched in 2014, the reform was implemented in 2017 in Zhejiang province and Shanghai; Launched in 2017, the reform will be implemented in 2020 in Beijing, Tianjin, Shandong, Hainan; Launched in 2018, the reform will be implemented in 2021 in Jiangsu, Hebei, Chongqing, Liaoning, Anhui, Fujian, Hunan, Hubei and Guangdong; Of the 15 provinces that have not implemented the reform, nine have postponed reform this year.

New Gaokao exam subject combinations, namely the " $3+1+2$ "

\begin{tabular}{|c|l|l|l|}
\hline \multicolumn{3}{|c|}{ '3+1+2'model } \\
\hline “3” & Unified exam & Chinese, Mathematics, Foreign language \\
\hline “1” & one out of two & Physics & History \\
\hline
\end{tabular}




\begin{tabular}{|c|c|c|c|}
\hline \multirow[t]{6}{*}{ “2” } & \multirow[t]{6}{*}{ two out of four } & Biology Chemistry & Biology Chemistry \\
\hline & & $\begin{array}{l}\text { Biology, Ideology and } \\
\text { politics }\end{array}$ & Biology, Ideology Politics \\
\hline & & Biology, Geography & Biology, Geography \\
\hline & & Chemistry, Geography & Chemistry, Geography \\
\hline & & $\begin{array}{l}\text { Ideology and Politics, } \\
\text { Geography }\end{array}$ & $\begin{array}{l}\text { Ideology and Politics, } \\
\text { Geography }\end{array}$ \\
\hline & & $\begin{array}{l}\text { Ideology and Politics, } \\
\text { Chemistry }\end{array}$ & $\begin{array}{l}\text { Ideology and Politics, } \\
\text { Chemistry }\end{array}$ \\
\hline
\end{tabular}

In China, the score is the determinant of what universities students are eligible to attend.,To be admitted into a first-class Chinese university, students are required to have a very strong ability to take exams with high Gaokao scores, or extraordinary ability to be picked by first-class universities. The following form is the minimum requirements and maximum preferential treatment for independent enrollment of Peking University and Tsinghua University. ${ }^{1}$

Table 3

\begin{tabular}{|l|l|l|c|c|}
\hline \multirow{2}{*}{ University } & \multicolumn{3}{|c|}{ Minimum requirements for independent enrollment } & \multicolumn{1}{|c|}{$\begin{array}{c}\text { Maximum pref- } \\
\text { erential treat- } \\
\text { ment(score) }\end{array}$} \\
\cline { 2 - 4 } $\begin{array}{l}\text { Peking } \\
\text { University }\end{array}$ & $\begin{array}{l}\text { Students who have won the } \\
\text { national finals of the five subject } \\
\text { competitions }\end{array}$ & $\begin{array}{l}\text { Students who have } \\
\text { won the national } \\
\text { finals of the five sub- } \\
\text { ject competitions }\end{array}$ & 60 & 2018 \\
\cline { 2 - 4 } & $\begin{array}{l}\text { Students who have made inven- } \\
\text { tions or participated in national } \\
\text { finals of science and technology } \\
\text { competitions or international } \\
\text { competitions with excellent } \\
\text { results }\end{array}$ & $\begin{array}{l}\text { Students who have } \\
\text { fon the national } \\
\text { finals of the five sub- } \\
\text { ject competitions }\end{array}$ & & \\
\cline { 2 - 4 } & $\begin{array}{l}\text { Those who have specialty in } \\
\text { related subjects and innovation } \\
\text { potential within the scope of } \\
\text { independent enrollment and } \\
\text { have achieved excellent results } \\
\text { in relevant specialized learning } \\
\text { and practice activities at home } \\
\text { and abroad }\end{array}$ & & & \\
\hline
\end{tabular}

${ }^{1}$ The five subject competitions are five subjects: index science, physics, information science, chemistry and biology. 


\begin{tabular}{|l|l|l|l|c|}
\hline $\begin{array}{l}\text { Tsinghua } \\
\text { University }\end{array}$ & $\begin{array}{l}\text { Students who have best perfor- } \\
\text { mance in five subject compe- } \\
\text { titions }\end{array}$ & $\begin{array}{l}\text { Winner of provincial } \\
\text { first prize or above } \\
\text { in five subject com- } \\
\text { petitions }\end{array}$ & 60 & 20 \\
\cline { 2 - 3 } & $\begin{array}{l}\text { Students who have outstanding } \\
\text { performance in scientific and } \\
\text { technological inventions, re- } \\
\text { search practice, literary creation } \\
\text { and other aspects }\end{array}$ & $\begin{array}{l}\text { Winner of national } \\
\text { first prize at the na- } \\
\text { tional youth science } \\
\text { and technology inno- } \\
\text { vation competition }\end{array}$ & & \\
\cline { 2 - 3 } & $\begin{array}{l}\text { Students who have outstanding } \\
\text { talent in humanities and society, } \\
\text { innovation and design, etc., or } \\
\text { who have achieved excellent } \\
\text { results in related learning prac- } \\
\text { tices }\end{array}$ & $\begin{array}{l}\text { Winner of fourth } \\
\text { prize at Intel inter- } \\
\text { national science and } \\
\text { engineering grand } \\
\text { prix }\end{array}$ & & \\
\hline
\end{tabular}

The first-class universities have different admission requirements and quota for each province in China Taking Tsinghua University as an example, we can see that the tier- 1 admission scores of Tsinghua University vary from one province to another.

Table 4

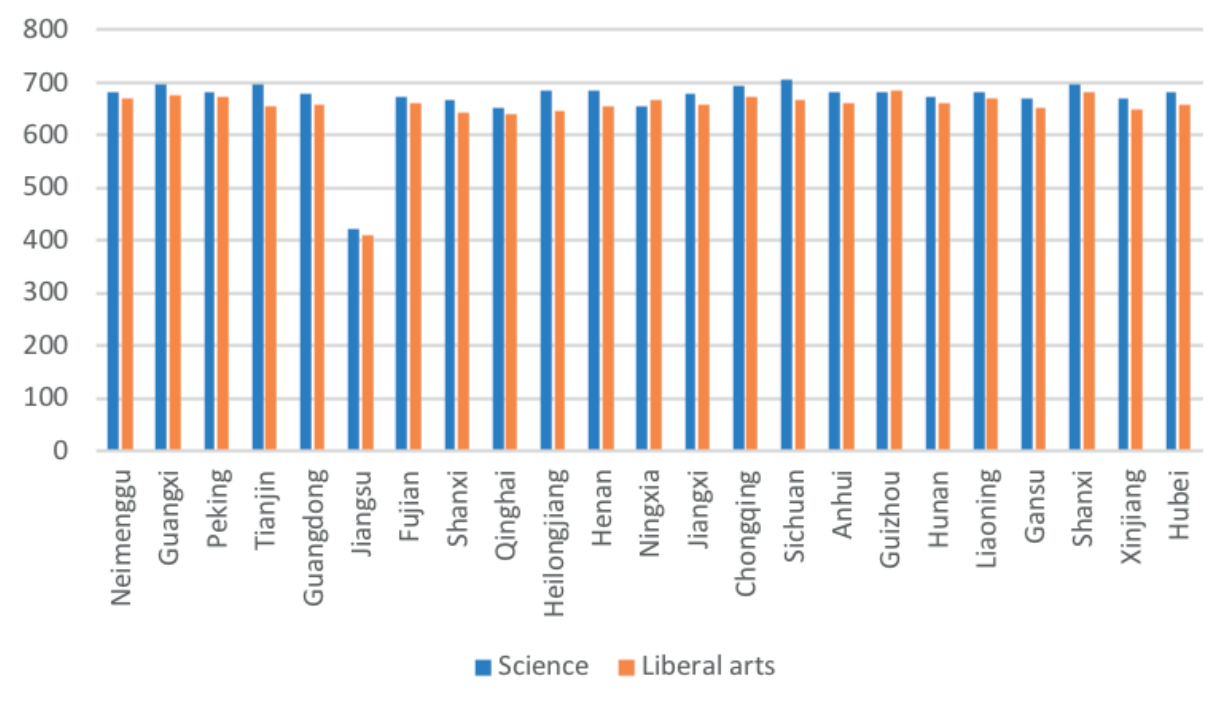

Therefore, to be admitted to China's elite universities, students need to achieve the entry scores of the desired university in their home provinces. It's not easy. 


\section{Chinese students in Poland today}

With the gradual implementation of the 'The Belt and Road' initiative ${ }^{2}$ of China, and the deepening of cooperation and exchange with Poland in various fields, more and more international students swarm into Poland. It can be found that after several years of practice, the quality of students coming to Poland has increased year by year. Among them, students and teachers from Tsinghua University, Beijing Foreign Studies University, Zhejiang University, and other top Chinese universities have came to Poland for exchange and continuing education, with excellent academic achievements. Some students get scholarships from the National Scholarship Program, and some are exchange students through the European Erasmas exchange system. Some of them come to Poland to study at their own expense, in addition to some academicians from the Chinese Academy of Sciences in Poland on academic visits.

In many popular destination countries, Chinese students account for the majority of the world's international student population. There are 72743 foreign students from 170 countries studying in Poland, over 6950 more than a year ago (over 10\% increase) in the academic year 2017/2018. ${ }^{3}$ But in Poland, Chinese students only account for a small portion of international student population, According to the statistics of the Chinese Embassy in Poland, in December 2018, there were about 1,400 Chinese students studying in Poland. This is very small compared to the number of Chinese students in other countries.

\section{Investigation of the Factors affecting Studying in Poland}

Variable declaration

\begin{tabular}{|l|l|l|}
\hline \multicolumn{1}{|c|}{ Variable name } & \multicolumn{1}{|c|}{ Variable } & \multicolumn{1}{c|}{ Note } \\
\hline Willingness to return & $\begin{array}{l}\text { Willingness to re- } \\
\text { turn:WR }\end{array}$ & Score 1 5 \\
\hline Willingness to stay Poland & $\begin{array}{l}\text { Willingness to } \\
\text { stay:WS }\end{array}$ & $\begin{array}{l}\text { no:0 } \\
\text { yes:1 }\end{array}$ \\
\hline
\end{tabular}

${ }^{2}$ The Belt and Road Initiative, the brainchild of Chinese President Xi Jinping, is an ambitious project that focuses on improving connectivity and cooperation among multiple countries across the continents of Asia, Africa, and Europe. Dubbed as the "Project of the Century" by the Chinese authorities, BRI spans about 78 countries.

${ }^{3}$ http://www.studyinpoland.pl/en/index.php/news/85-foreign-students-in-polandnumbers-and-fac 


\begin{tabular}{|c|c|c|}
\hline Gender & Gender & female $=0 ;$ male $=1$ \\
\hline Degree & Degree & $\begin{array}{l}\text { Preparatory course }=0 ; \text { Bache- } \\
\text { lor's degree }=1 ; \text { master's degree } \\
=2 ; \text { Doctor's degree }=3\end{array}$ \\
\hline Difficulty of Application & $\begin{array}{l}\text { Difficulty of Applica- } \\
\text { tion:DA }\end{array}$ & Score $1 \sim 5$ \\
\hline $\begin{array}{l}\text { Relative difficulty of appli- } \\
\text { cation China }\end{array}$ & $\begin{array}{l}\text { Relative difficulty } \\
\text { of application (Chi- } \\
\text { na):RDAC }\end{array}$ & Easier $=0 ;$ more difficult $=1$ \\
\hline $\begin{array}{l}\text { Relative difficulty of appli- } \\
\text { cation others }\end{array}$ & $\begin{array}{l}\text { Relative difficulty of } \\
\text { application(others):R- } \\
\text { DAO }\end{array}$ & Easier $=0 ;$ more difficult $=1$ \\
\hline Difficulty of Course & $\begin{array}{l}\text { Difficulty of Cour- } \\
\text { se:DC }\end{array}$ & Score $1 \sim 5$ \\
\hline Difficulty of Graduation & $\begin{array}{l}\text { Difficulty of Gradu- } \\
\text { ation:DG }\end{array}$ & Score $1 \sim 5$ \\
\hline Prospects & Prospects & $\begin{array}{l}\text { Back to China }=0 \\
\text { Stay in Poland }=1\end{array}$ \\
\hline Source of tuition & Source of tuition:ST & $\begin{array}{l}\text { From parents or family }=0 ; \text { From } \\
\text { personal savings }=1 \text {; Government } \\
\text { expense or exchange program }=2 \text {; } \\
\text { other }=3\end{array}$ \\
\hline Tuition acceptance & $\begin{array}{l}\text { Tuition acceptan- } \\
\text { ce:AT }\end{array}$ & $\begin{array}{l}\text { expensive }=0 \\
\text { not expensive }=1\end{array}$ \\
\hline $\begin{array}{l}\text { Polish Food or Chinese } \\
\text { food }\end{array}$ & Food & $\begin{array}{l}\text { Chinese food }=0 \\
\text { Polish food }=1 £ \neg \text { both }=2\end{array}$ \\
\hline Source of living expenses & $\begin{array}{l}\text { Source of living ex- } \\
\text { penses:SL }\end{array}$ & $\begin{array}{l}\text { From parents or family }=0 \text {;Per- } \\
\text { sonal savings or part-time in- } \\
\text { come }=1 \text {; } \\
\text { At public expense }=2\end{array}$ \\
\hline Living expenses acceptance & $\begin{array}{l}\text { Living expenses ac- } \\
\text { ceptance:AL }\end{array}$ & $\begin{array}{l}\text { well-off }=0 ; \\
\text { not well-off=1 }\end{array}$ \\
\hline part-time job & part-time job:PTJ & yes=0;no=1 \\
\hline Willing to learn Polish & Learn Polish:Polish & yes=0;no=1 \\
\hline $\begin{array}{l}\text { Plan to go to other coun- } \\
\text { tries to live }\end{array}$ & $\begin{array}{l}\text { other countries to } \\
\text { live:OC }\end{array}$ & yes $=0 ;$ no $=1$ \\
\hline Impression of the Poles & $\begin{array}{l}\text { Impression of the } \\
\text { Poles:IP }\end{array}$ & Score $1 \sim 5$ \\
\hline $\begin{array}{l}\text { Work attitude and work } \\
\text { efficiency of the Poles }\end{array}$ & $\begin{array}{l}\text { Work attitude and } \\
\text { work efficiency of the } \\
\text { Poles:WP }\end{array}$ & Score $1 \sim 5$ \\
\hline
\end{tabular}




\section{Description of variable}

(include: Freq., Percent and Cum.)

Tabulation

Table 6

\begin{tabular}{|c|c|c|c|c|}
\hline & & Freq. & Percent. & Cum. \\
\hline \multirow{5}{*}{ WR } & 1 & 5 & 4.17 & 4.17 \\
\hline & 2 & 10 & 8.33 & 12.50 \\
\hline & 3 & 45 & 37.50 & 50.00 \\
\hline & 4 & 18 & 15.00 & 65.00 \\
\hline & 5 & 42 & 35.00 & 100.00 \\
\hline \multirow[t]{2}{*}{ WS } & 0 & 47 & 39.17 & 39.17 \\
\hline & 1 & 73 & 60.83 & 100.00 \\
\hline \multirow[t]{2}{*}{ Gender } & 0 & 72 & 60.00 & 60.00 \\
\hline & 1 & 48 & 40.00 & 100.00 \\
\hline \multirow[t]{4}{*}{ Degree } & 0 & 8 & 6.67 & 6.67 \\
\hline & 1 & 40 & 33.33 & 40.00 \\
\hline & 2 & 53 & 44.17 & 84.17 \\
\hline & 3 & 19 & 15.83 & 100.00 \\
\hline \multirow[t]{4}{*}{$\mathrm{DA}$} & 1 & 31 & 25.83 & 25.83 \\
\hline & 2 & 28 & 23.33 & 49.17 \\
\hline & 3 & 55 & 45.83 & 95.00 \\
\hline & 4 & 6 & 5.00 & 100.00 \\
\hline \multirow[t]{2}{*}{ RDAC } & 0 & 107 & 89.17 & 89.17 \\
\hline & 1 & 13 & 10.83 & 100.00 \\
\hline \multirow[t]{2}{*}{ RDAO } & 0 & 116 & 96.67 & 96.67 \\
\hline & 1 & 4 & 3.33 & 100.00 \\
\hline \multirow[t]{5}{*}{$\mathrm{DC}$} & 1 & 6 & 5.00 & 5.00 \\
\hline & 2 & 17 & 14.17 & 19.17 \\
\hline & 3 & 72 & 60.00 & 79.17 \\
\hline & 4 & 21 & 17.50 & 96.67 \\
\hline & 5 & 4 & 3.33 & 100.00 \\
\hline
\end{tabular}




\begin{tabular}{|c|c|c|c|c|}
\hline \multirow[t]{5}{*}{ DG } & 1 & 4 & 3.33 & 3.33 \\
\hline & 2 & 15 & 12.50 & 15.83 \\
\hline & 3 & 64 & 53.33 & 69.17 \\
\hline & 4 & 29 & 24.17 & 93.33 \\
\hline & 5 & 8 & 6.67 & 100.00 \\
\hline \multirow[t]{2}{*}{ Prospects } & 0 & 92 & 76.67 & 76.67 \\
\hline & 1 & 28 & 23.33 & 100.00 \\
\hline \multirow[t]{3}{*}{ ST } & 0 & 90 & 75.00 & 75.00 \\
\hline & 1 & 4 & 3.33 & 78.33 \\
\hline & 2 & 26 & 21.67 & 100.00 \\
\hline \multirow[t]{2}{*}{$\mathrm{AT}$} & 0 & 10 & 8.33 & 8.33 \\
\hline & 1 & 110 & 91.67 & 100.00 \\
\hline \multirow[t]{3}{*}{ FOOD } & 0 & 91 & 75.83 & 75.83 \\
\hline & 1 & 1 & 0.83 & 76.67 \\
\hline & 2 & 28 & 23.33 & 100.00 \\
\hline \multirow[t]{3}{*}{ SL } & 0 & 87 & 72.50 & 72.50 \\
\hline & 1 & 10 & 8.33 & 80.83 \\
\hline & 2 & 23 & 19.17 & 100.00 \\
\hline \multirow[t]{2}{*}{$\mathrm{AL}$} & 0 & 80 & 66.67 & 66.67 \\
\hline & 1 & 40 & 33.33 & 100.00 \\
\hline \multirow[t]{2}{*}{ PTW } & 0 & 36 & 30.00 & 30.00 \\
\hline & 1 & 84 & 70.00 & 100.00 \\
\hline \multirow[t]{2}{*}{ Polish } & 0 & 72 & 60.00 & 60.00 \\
\hline & 1 & 48 & 40.00 & 100.00 \\
\hline \multirow[t]{2}{*}{ OC } & 0 & 99 & 82.50 & 82.50 \\
\hline & 1 & 21 & 17.50 & 100.00 \\
\hline \multirow[t]{5}{*}{ IP } & 1 & 3 & 2.50 & 2.50 \\
\hline & 2 & 3 & 2.50 & 5.00 \\
\hline & 3 & 39 & 32.50 & 37.50 \\
\hline & 4 & 47 & 39.17 & 76.67 \\
\hline & 5 & 28 & 23.33 & 100.00 \\
\hline \multirow[t]{5}{*}{ WP } & 1 & 22 & 18.33 & 18.33 \\
\hline & 2 & 39 & 32.50 & 50.83 \\
\hline & 3 & 46 & 38.33 & 89.17 \\
\hline & 4 & 12 & 10.00 & 99.17 \\
\hline & 5 & 1 & 0.83 & 100.00 \\
\hline
\end{tabular}


Logistic regression

Table 7

\begin{tabular}{|c|c|c|c|c|c|c|c|}
\hline WS & Coef. & $\begin{array}{l}\text { Odds } \\
\text { Ratio }\end{array}$ & $\begin{array}{c}\mathrm{Z}- \\
\text { value }\end{array}$ & $\begin{array}{c}\mathrm{p}- \\
\text { value }\end{array}$ & $\begin{array}{l}{[95 \%} \\
\text { Conf }\end{array}$ & Interval] & Sig \\
\hline Prospects & 1.000 & & & & & & \\
\hline 1.Prospects & 15.612 & 8.990 & 4.77 & 0.000 & 5.050 & 48.263 & $* * *$ \\
\hline Food & 1.000 & & & & & & \\
\hline 2.Food & 1.279 & 0.753 & 0.42 & 0.676 & 0.403 & 4.054 & \\
\hline Polish & 1.000 & & & & & & \\
\hline 1.Polish & 0.297 & 0.153 & -2.36 & 0.018 & 0.108 & 0.815 & $* *$ \\
\hline OC & 1.000 & & & & & & \\
\hline $1 . \mathrm{OC}$ & 0.340 & 0.222 & -1.65 & 0.098 & 0.094 & 1.221 & * \\
\hline IP & 0.708 & 0.223 & -1.09 & 0.274 & 0.382 & 1.314 & \\
\hline WP & 2.276 & 0.739 & 2.53 & 0.011 & 1.204 & 4.302 & $* *$ \\
\hline Constant & 0.528 & 0.744 & -0.45 & 0.650 & 0.033 & 8.336 & \\
\hline \multicolumn{2}{|c|}{ Mean dependent var } & 0.605 & \multicolumn{3}{|c|}{ SD dependent var } & 0.491 & \\
\hline \multicolumn{2}{|c|}{ Pseudo r-squared } & 0.330 & \multicolumn{3}{|c|}{ Number of obs } & 119.000 & \\
\hline \multicolumn{2}{|l|}{ Chi-square } & 52.665 & \multicolumn{3}{|l|}{ Prob > chi2 } & 0.000 & \\
\hline \multicolumn{2}{|c|}{ Akaike crit. (AIC) } & 121.013 & \multicolumn{3}{|c|}{ Bayesian crit. (BIC) } & 140.467 & \\
\hline
\end{tabular}

${ }^{* * *} \mathrm{p}<0.01,{ }^{* *} \mathrm{p}<0.05,{ }^{*} \mathrm{p}<0.1$

Logistic regression

Table 8

\begin{tabular}{|c|c|c|c|c|c|c|c|}
\hline WS & Coef. & $\begin{array}{l}\text { Odds } \\
\text { Ratio }\end{array}$ & $\begin{array}{c}\text { Z- } \\
\text { value }\end{array}$ & $\begin{array}{c}\mathrm{p}- \\
\text { value }\end{array}$ & $\begin{array}{l}{[95 \%} \\
\text { Conf }\end{array}$ & Interval] & Sig \\
\hline Prospects & 1.000 & & & & & & \\
\hline 1.Prospects & 15.612 & 8.990 & 4.77 & 0.000 & 5.050 & 48.263 & $* * *$ \\
\hline Food & 1.000 & & & & & & \\
\hline 2.Food & 1.279 & 0.753 & 0.42 & 0.676 & 0.403 & 4.054 & \\
\hline Polish & 1.000 & & & & & & \\
\hline 1.Polish & 0.297 & 0.153 & -2.36 & 0.018 & 0.108 & 0.815 & $* *$ \\
\hline $\mathrm{OC}$ & 1.000 & & & & & & \\
\hline $1 . \mathrm{OC}$ & 0.340 & 0.222 & -1.65 & 0.098 & 0.094 & 1.221 & * \\
\hline IP & 0.708 & 0.223 & -1.09 & 0.274 & 0.382 & 1.314 & \\
\hline $\mathrm{WP}$ & 2.276 & 0.739 & 2.53 & 0.011 & 1.204 & 4.302 & ** \\
\hline Constant & 0.528 & 0.744 & -0.45 & 0.650 & 0.033 & 8.336 & \\
\hline
\end{tabular}




\begin{tabular}{|l|l|l|l|l|}
\hline Mean dependent var & 0.605 & SD dependent var & 0.491 & \\
\hline Pseudo r-squared & 0.330 & Number of obs. & 119.000 & \\
\hline Chi-square & 52.665 & Prob > chi2 & 0.000 & \\
\hline Akaike crit. (AIC) & 121.013 & Bayesian crit. (BIC) & 140.467 & \\
\hline
\end{tabular}

${ }^{* * *} \mathrm{p}<0.01,{ }^{* *} \mathrm{p}<0.05,{ }^{*} \mathrm{p}<0.1$

\section{Application requirements and tuitions of Polish universities}

Requirements for application to Polish universities

Table 9

\begin{tabular}{|c|c|c|}
\hline Degree & Materials & Remarks \\
\hline Prep class & $\begin{array}{l}\text { High school diploma } \\
\text { College entrance exam results or } \\
\text { transcript of junior college }\end{array}$ & \multirow{3}{*}{$\begin{array}{l}\text { Personal resume, letter of } \\
\text { recommendation and he- } \\
\text { alth certificate are required } \\
\text { when necessary. Collection of } \\
\text { works and entrance exam are } \\
\text { required for special majors } \\
\text { such as art. Health certificate of } \\
\text { fixed template and transcript of } \\
\text { specialized courses or intern- } \\
\text { ship certificate are required for } \\
\text { medical major. Some schools } \\
\text { would examine language com- } \\
\text { petence in a flexible manner, } \\
\text { for example, interview can be } \\
\text { arranged in absence of langu- } \\
\text { age certificate. }\end{array}$} \\
\hline Undergraduate & $\begin{array}{l}\text { High school diploma } \\
\text { College entrance exam results or } \\
\text { transcript of junior college } \\
\text { Language certificate (TOFEL, } \\
\text { IELTS, Polish B1-B2) }\end{array}$ & \\
\hline Postgraduate & $\begin{array}{l}\text { Certificate of undergraduate degree } \\
\text { Undergraduate diploma } \\
\text { Transcript of undergraduate cour- } \\
\text { ses } \\
\text { Language certificate (TOFEL, } \\
\text { IELTS, Polish B1-B2) }\end{array}$ & \\
\hline Doctoral & $\begin{array}{l}\text { Certificate of postgraduate degree } \\
\text { Transcript of postgraduate courses } \\
\text { Personal resume } \\
\text { Letter of recommendation from } \\
\text { tutor } \\
\text { Confirmation of acceptance from } \\
\text { doctoral supervisor with the intend- } \\
\text { ed school } \\
\text { Language certificate (TOFEL, } \\
\text { IELTS, Polish B1-B2) }\end{array}$ & $\begin{array}{l}\text { Some schools would also re- } \\
\text { quire evidence of engagement } \\
\text { in related work or research and } \\
\text { specialized thesis. The opin- } \\
\text { ion of the doctoral supervisor } \\
\text { would play a decisive role in } \\
\text { application for doctoral degree. }\end{array}$ \\
\hline Visiting scholar & $\begin{array}{l}\text { Application letter provided by Chi- } \\
\text { nese universities or institutions } \\
\text { Certificate of highest degree } \\
\text { achieved }\end{array}$ & \\
\hline
\end{tabular}




\begin{tabular}{|l|l|l|}
\hline Visiting scholar & $\begin{array}{l}\text { Certificate of recent research find- } \\
\text { ings } \\
\text { Letter of motivation } \\
\text { Language certificate }\end{array}$ & \\
\hline
\end{tabular}

Currently, the following documents are required for application to Polish universities. College entrance exam results have no effect on enrollment, although CEE results are required when applying to Polish universities. For now, many famous overseas universities have recognized China's CEE results and it is less difficult to get admitted to Polish universities than popular universities in other countries.

The tuition for studying in Poland is summarized as follows:

Table 10

\begin{tabular}{|l|c|}
\hline \multicolumn{1}{|c|}{ Major } & Euro/year \\
\hline General majors, such as art, science and business & $2000 \sim 3500$ \\
\hline Art majors, such as music, piano, painting and performance & $\sim 7000$ \\
\hline Medical majors, such as medicine and dentistry & $\sim 14000$ \\
\hline Tuition in Warsaw for the same majors & $20 \%-30 \%$ higher \\
\hline
\end{tabular}

Tuitions in Poland are all specified by the Polish Ministry of Education or Polish Ministry of Culture and may be adjusted by schools as necessary. Scholarships are available at Polish schools for academic excellence and the Chinese government also offers outstanding student scholarship.

\section{Analysis}

WR results indicate that $35 \%$ of respondents are highly willing to return to home countries, $37.5 \%$ moderately willing and only 5 least willing, accounting for $4.17 \%$ of sample population; WS results indicate that $60.83 \%$ of respondents will choose to stay in Poland for work and study if given a chance, suggesting that international students in Poland quite identify themselves with this country. But $39.17 \%$ of students still choose to return to home countries even if given a chance to study in Poland for study and living, suggesting that these students chose to study in Poland truly for the sake of education or because of the international recognition of these Polish universities in terms of particular specialties. 
Gender results indicate that the male-female ratio is 4:6 among the international students in Poland, suggesting that Polish universities are favored more by female students; Degree results indicate that $44.17 \%$ of international students in Poland are masters, followed by undergraduate students who account for $33.33 \%$, while prep course students and doctoral students account for $6.67 \%$ and $15.83 \%$ of sample population respectively.

DA results indicate that $95 \%$ of sampled international students in Poland have less than 3 points on a scale of five points, therefore it is believed that it is easier to make successful application; RDAC results indicate that $89.17 \%$ of respondents believe it is easy to go to Polish universities; RDAO results indicate that $96.67 \%$ of respondents believe it is easy to go to Polish universities compared with other popular universities. The aforesaid three survey questions suggest that the relative ease of application to Polish universities is a major factor affecting application.

DC results show that $79.17 \%$ of sampled international students in Poland have less than 3 points, while DG results indicate the percentage is $69.17 \%$, suggesting that the courses are not particularly difficult.

Prospects results show that $76.67 \%$ of respondents believe returning to home countries for jobs is promising, a very large proportion.

ST results show that $75 \%$ of respondents are funded by parents or family members, merely $3.33 \%$ by personal savings and $21.67 \%$ by public funding. AT results show that only $8.33 \%$ of respondents consider the tuitions expensive. Tuitions might be a reason why international students choose to study in Poland.

Food results indicate that only $0.83 \%$ of respondents prefer Polish food over Chinese food, suggesting that food is not a factor affecting the decision to study in Poland.

SL results show that the major source of living expense is family support, comparable to the source of tuition. Therefore, most of international students studying in Poland are self-financed.

AL results show that two thirds of respondents believe they have no financial difficulties; PTW results indicate that only $30 \%$ of respondents have done part-time jobs. Polish results show that $60 \%$ of respondents love and want to learn Polish, indicating a large proportion of respondents want to get involved in local culture and life.

OC results show that $82.50 \%$ of respondents want to study and seek career prospects in other countries after graduation, suggesting that the international students in Poland have a high level of international vision.

IP results show that only $5 \%$ of respondents think negatively of Polish people, $37.5 \%$ say OK and $62.5 \%$ have good impression of Polish people. 
WP results show that $50.82 \%$ of respondents do not recognize the work efficiency of Polish people ( 1 or 2 points on a scale of 1 to 5 ) and $10.83 \%$ think otherwise (4 or 5 points on a scale of 1 to 5 ).

Research finding show that the odds ratio of staying in Poland is 0.297 for each additional degree in loving Polish, meaning the more international students love Polish, the easier they would choose to stay in Poland. The odds ratio of staying in Poland is 2.276 for each additional level in the recognition of Polish work attitude and efficiency by international students, meaning the more international students recognize Polish work attitude and efficiency, the easier they would choose to stay in Poland. The willingness to return to home countries would reduce with each additional degree in their longing for other countries.

\section{Conclusion and discussion}

Studying in Poland is an important attempt for Chinese students, while both the Chinese and Polish sides expect to select the talented people with technical expertise and capabilities to adapt to the current social development through this attempt, thus breaking through the drawbacks and limitations of Chinese education. Chinese students also want to have professional knowledge and overall capabilities matching the national and world situation through studying in Poland. The future of studying in Poland largely depends on the deep exchange and friendship between China and Poland and whether Chinese students have a deep and comprehensive understanding of Poland, which also requires related policy support. This paper analyzes the factors affecting Chinese students' decision to study in Poland using the sample survey findings from Chinese students studying in Poland. The research findings show that the reasons Chinese students chose to study in Poland mainly include the ease of application to Polish universities and the low tuition and international recognition enjoyed by some Polish universities for their specialties. In addition, how much international students love Polish is another factor affecting their decision to stay in Poland after graduation, and the recognition of Polish work attitude and efficiency also affects Chinese students' decision to stay in Poland.

The examination of studying abroad is comprehensive and all-round, and the decision to study in Poland depends largely upon the scientific and normative nature of the recruitment criteria and selection process. Compared with admission process of Chinese universities, Polish enrollment policy is transparent, but selection criteria are not specific enough, especially conside- 
ring that the assessments of different experts in interviews are considerably subjective and random. Polish universities are expected to give overall consideration to the appraisal indicators in the actual enrollment process so as to provide greater support for outputting talented people to the world. Of course, the easy application and low tuition also give applicants more chances to get admitted to outstanding Polish universities, thus understanding and loving Poland. This is beneficial to the long-term friendly exchange between China and Poland. The national conditions of China mean that most of Chinese people have to live at a fast pace and work efficiently, as opposed to the slow pace of life prevalent in Europe, so it is understandable that Chinese students think Polish work efficiency is low. The language factor is a reason Chinese students choose not to stay in Poland after graduation, as the official language of Poland is Polish, which is completely strange to Chinese people and very difficult to learn without huge efforts. Inability to use Polish means a much less chance to get employed. Meanwhile, the average wage in Poland is much lower than that in China, well below the wage expectation of Chinese students. All of the above are the factors affecting Chinese people's decision to stay in Poland, including Chinese students.

\section{BIBLIGRAPHY}

Opinions on Deepening Reform on Examination \& Recruitment System [EB/OL].3.9.2014. Ma Liping \& Bu Shangcong, The Effects of the Independent Admission Policy of Talent Selection in Chinese Elite Universities, Peking University Education Review, April, 2019, 17, 2, 109-126.

Fei Yue, Study abroad market set off "Poland", Work \& Studing Abroad, 12-14.

Zhi Cheng Yang, Viewing the Reform of the New College Entrance Examination from Three Changes, Beijing Daily, Xinzhi Weekly, 2019, 26, 6, 016.1-2.

Bing Zhou, The Science Educaion Article Collects. An Analysis of the Status Quo and Factors of Chinese Returned Students in Canada, May, 2017, Total 385, 139-140.

GUO Xiao-xian \& CAO Wen-wen, Educaiton Teaching Forum, The Acculturation in Germany from the perspective of Cross-Cultural Communication for Chinese Overseas Students, May, 2018, 58-59.

Xin Liu, The Research of College Student Education Management in the Complete Credit System, 18.9.2016.

YU Jiajun, A Studay on Learning-centered Evaluation of College Teaching, October, 2015.

http://old.moe.gov.cn//publicfiles/business/htmlfiles/moe/s5147/201409/174589. $\mathrm{html}$

https://homestay.cambridgenetwork.com/blog/new-gaokao-means-students-china/

http://m.djzbl.com/djz/22415/323249.html

https:// baike.baidu.com/item/普通高等学校招生全国统一考试/2567351?fromtitle=高 考\&fromid $=219910$

http://baike.baidu.com/item/. 